\title{
POSSIBILITIES OF DESIGNATING SWARDS OF GRASSES AND SMALL-SEED LEGUMES FROM SELECTED ORGANIC FARMS IN POLAND FOR FEED
}

\author{
Anna SZELĄG-SIKORA ${ }^{\mathbf{1}}$, Marcin NIEMIEC ${ }^{2}$, Jakub SIKORA ${ }^{\mathbf{1}}$, \\ Maciej CHOWANIAK ${ }^{2}$ \\ ${ }^{1}$ University of Agriculture in Krakow, Faculty of Production and Power Engineering, POLAND \\ ${ }^{2}$ University of Agriculture in Krakow, Faculty of Agriculture and Economics, POLAND \\ E-mail of corresponding author: anna.szelag-sikora@ur.krakow.pl
}

Keywords: organic farm, animal production farms, chemical composition of the feed

\begin{abstract}
Proper management of plant nutrients has a fundamental effect on the amount and quality of crop yields and on maintaining soil fertility. Under organic production conditions, with limited fertilization, deficiency of some elements in soil may occur, which translates into a change in the chemism of cultivated plants. The aim of this paper was to assess the quality of a sward from selected organic farms in the context of using it for feed purposes. 55 organic farms were selected for the research; 25 of those farms additionally had conventional animal production. Sward samples of mixed grasses and small-seed legumes were collected from each farm. Content of elements that are the most determinant on the suitability for feed $(\mathrm{N}, \mathrm{P}, \mathrm{K}, \mathrm{Na}, \mathrm{Ca}, \mathrm{Na})$ was determined in the plant material. The results of the conducted research indicate that sward from grasses and small-seed legumes from the studied organic farms had too low content of macroelements and of most microelements, and the biggest problem was too low content of phosphorus, potassium and calcium. The animal production farms were found to have a higher content of phosphorus, calcium and potassium in sward as compared to farms without animals. Feeding cattle only with roughage obtained from the studied lands could pose a risk to the health of the animals and their productive abilities owing to the unfavorable chemical composition.
\end{abstract}

\section{INTRODUCTION}

The idea of organic farming is a result of intensification of food production and the negative effect of farming on the natural environment that is associated with this production. Increasing plant production capacity involves increasing the amount of used fertilizers and chemical pesticides, intensification of soil degradation processes and unfavorable changes in agricultural landscape (Niemiec et al. 2015; Lorenz and Lal 2016). Intensive animal production leads to local contamination of the environment as a result of storing natural fertilizers and feeds. The most frequently described problems associated with concentration of animal production include local odor nuisance, the risk of microbiological contamination, and pollution and contamination of surface and underground waters. In addition, intensive farming of animals leads to problems associated with managing animal health and imposes the use of a higher amount of allopathic veterinary medicines. Ethics, which has recently been gaining in significance, is an important aspect of food production (Carlsson et al. 2007, Kubon at al. 2010). The increasingly aware consumer seeks products that are of verifiably better quality but that have also been produced using environmentally-friendly technologies, respecting animal rights and workers' rights. There are many quality systems (both private and currently operating in the EU) in the market which are optionally implemented by farmers (Higgins et al. 2008). Organic farming is one of the most restrictive systems. Its goal is to return, as much as possible, to the original methods of food production with limiting the use of external means of production to the maximum (Niemiec at al. 2016). The purpose of such an approach is to generate high quality products, both in sensory terms and in terms of chemical composition. Processes that are used to produce organic 
products should, as much as possible, use natural productive capacities of ecosystems and processing techniques which do not alter the properties of the product and do not reconstruct its features that have been lost as a result of processing. In animal production, it is important to ensure well-being of animals in inventory buildings and to provide them with activities resulting from behaviorism. Organic animal production ecological should be based on selecting animal breeds resistant to diseases and unfavorable climatic conditions, and managing their health is associated with ensuring proper living conditions for animals and feeding at a level that meets the nutrient demand of animals. Due to reduced fertilization on ecologically used areas, there is a risk that the quality of feed produced under ecological management conditions will not meet the requirements laid for good quality feeds.

The aim of this paper was to assess the quality of a sward from selected organic farms in the context of using it for feed purposes.

\section{MATERIAL AND METHODS}

To achieve the objective established in 2016, research was conducted in 55 organic farms. All the farms had been subjected to a system of control and certification of the certification body, and based on the inspections performed in 2015 they met the requirements of the EC Regulation No. 834/2007 of 28 June 2007 on organic production and labelling of organic products and repealing Regulation (EEC) No. 2092/91. All the farms had been converted. The studied farms were located in Dolnośląskie (17), Lubuskie (13), and Warmińsko-Mazurskie (25) provinces. Among the studied farms, 25 had conventional livestock production. All farms with animal production were located in Warmińsko-Mazurskie province. The area of the studied farms ranged from 30 to 90 ha. A sample of sward from the first crop was collected from each farm, from a randomly selected field. On all fields from which samples were collected, a perennial mix of grasses and small-seed legumes was grown, with different share of legumes. The share of legumes resulted from changes in the species composition of the sward which were caused by habitat and climatic conditions. The collected samples of sward were dried, homogenized and subjected to analysis. Content of elements that are the most determinant on suitability for feed $(\mathrm{N}, \mathrm{P}, \mathrm{K}, \mathrm{Na}, \mathrm{Ca}, \mathrm{Na}$ ) was determined in the plant material. The plant samples were subjected to dry mineralization in an open system in a muffle furnace at $450^{\circ} \mathrm{C}$. Then they were diluted in nitric acid solution. The analytical sample was $3 \mathrm{~g}$ dry matter. Concentration of the studied elements in the obtained solutions was determined by atomic emission spectrometry, on an Optima 7600 manufactured by PerkinElmer. Total nitrogen content was determined by elemental analysis method, using Elementar vario MAX cube elemental analyzer.

\section{RESULT AND DISCUSSION}

Organic fertilization on ecologically cultivated soils leads to an increase in soil fertility, enables proper plant feeding and makes it possible to maintain good soil culture (Niemiec et al. 2017). From the point of view production technology, maintaining ruminants, where feeding is based on the grazing system, is regarded as organic animal production which poses the fewest problems. Procuring feed from pastures is the most energy-efficient form of animal production. Maintenance of pastures is also beneficial from the point of view of carbon sequestration and reducing dispersion of nitrogen in the environment (Anglade et al. 2015). 
Phosphorus is a strategic element in organic farming and its deficiency is often observed, which is associated with lack of fast soluble fertilizers containing this element that are approved for use in organic farming (Barszczewski et al. 2007). The mean phosphorus content in sward biomass from the organic farms without animal production was $0.123 \%$ and ranged between 0.0713 and $0.215 \%$ (Tab. 1). Sward biomass from farms with animal production contained, on average, $0.169 \%$. The lowest phosphorus content in samples from this group was at the level of $0.123 \%$, whereas the highest was $0.252 \%$ (Tab. 1). Phosphorus content in the studied sward, both from farms with animal production and from the ones without cattle breeding, was too low from the point of view of intending the sward for feed. Good quality feed for dairy cows should contain at least $0.3 \%$ of this element. In the case of beef cattle breeding, phosphorus content above $0.17 \%$ should suffice (Mc Dowell, 1996). When phosphorus content in feed is too low, there can be problems with animal health associated with the limited ability to move, osteopathic lesions, and with problems with reproduction (Eisenberg et al. 2014). The problem of macro element deficiency in cattle eating feed from one source was emphasized particularly by Mc Dowell (1996) and McNamara et al. (2017). In such cases, it is necessary to supplement elements whose amounts in feed are insufficient, or to change the fertilization level for crop production with a better chemical composition (Alvarez-Fuentes et al. 2016). The range of optimal magnesium content in feed for beef cattle fluctuates from 0.05 to $0.25 \%$ (Mc Dowell, 1996). Too low content of this element in feed leads to increased animal sensitivity to stress, muscle tremors, numbness, irritability, anxiety. Zielińska et al. (2014) determined the amount of this element in sward of organic agricultural lands fertilized with manure at a level slightly below $0.2 \%$. Kulik (2009) recorded similar amounts in sward of traditional grass crops with small-seed legumes. Mean magnesium content in the studied samples of sward which are intended for feed amounted to $0.178 \%$ and no significant changes between the studied groups of farms were detected (Tab. 1). The determined amounts of magnesium are sufficient to satisfy the physiological requirements of cattle.

From the point of view of animal health and productivity, calcium content in feed is very important. Hypocalcemia is a very common problem associated with the management of dairy cow health. Hypocalcemia can be associated both with a low amount of this element in feed and with the impairment of mechanisms of its absorption. Symptoms of calcium deficiency are associated with animal weakness, apathy and lack of appetite. Calcium content that covers the nutrient requirements of dairy cows should not be lower than $0.43 \%$, whereas in the case of beef cows $-0.17 \%$ (McDowell, 1996). The results of the performed analyses point to a very low calcium content in the sward from organic farms. The mean content of this element in the sward from farms with animal production was $0.326 \%$, whereas in farms with only plant production it was much lower and amounted to 0.266\% (Tab. 1). Kulik (2009) reported that calcium content in the sward of mixed grasses and legumes was at the level exceeding $0.6 \%$, while Zielińska et al. (2014) reported that calcium content in the sward from organic pastures ranged from 0.3 to $0.7 \%$. Potassium is an element whose deficiency in cow diet occurs rarely. However, on account of a substantial variability of its amount in plants, potassium has a major effect on the shape of ionic ratio in feed (Rérat et al. 2009). The mean potassium content in the studied samples was $0.499 \%$ and ranged between 0.254 and $0.891 \%$ (Tab. 1). The optimum amount of potassium in feed for cattle should be approximately 2\% (McDowell, 1996) All the studied samples had potassium content that should have disqualified them as a feed material. There was no 
statistically significant difference in the content of this element in plant biomass from both research groups. The determined potassium content was several times lower than that recorded by Kulik (2009) in a sward of mixed grasses and small-seed legumes.

Sodium content in the studied samples of sward varied within a wide range from 0.007 to $0.100 \%$. A higher content (by approximately $40 \%$ ) of this element was observed in the sward obtained in animal production farms. Cattle feed should contain this element in the amount of approximately $0.1 \%$ (McDowell, 1996). In most cases, the determined amounts of sodium are too low and cannot meet the animal requirement for this element. Zielińska et al. (2014) recorded that sodium in the sward from organic pastures was in the amount of approximately $0.1 \%$. Sodium is a very important element in cattle diet, and under conditions of high animal productivity one cannot meet animal requirements for this element through feed alone; its supplementation in the form of salt-licks is required (Granzin and Gaughan, 2002).

Feed quality from the point of view of its chemical composition is assessed not only based on content of elements in it, but also on the ratio between them. The optimum mass ratio calcium to phosphorus $(\mathrm{Ca}: \mathrm{P})$ in feed should range from 1.3 to 2.0 (McDowell, 1996). The value of the Ca:P mass ratio in the sward from individual farms ranged between 1.146 and 4.614 (Tab. 1). Half of the samples from farms without animal production had improper quantitative ratio between the studied elements. In farms with animal production, more beneficial relationships between phosphorus content and calcium content were observed. In $20 \%$ of cases the $\mathrm{Ca}: \mathrm{P}$ ratio was too high. Results obtained by Zielińska et al. (2014) in the sward from organic pastures were similar to the results observed in our research. Too high quantitative ratio of $\mathrm{Ca}: \mathrm{P}$ leads to a reduction in phosphorus absorption by the animal organism even with its high amount in feed. The ionic ratio of $\mathrm{K}:(\mathrm{Ca}+\mathrm{Mg})$ is another parameter that shapes the quality of feed. The value of this parameter should not be lower than 1.6 and should not exceed 2.2 (Falkowski et al. 2000). The results of the conducted research indicate that none of the samples of sward meets the criteria for a good quality feed from the point of view of the ionic ratio of potassium to the sum of calcium and magnesium. Too low values of this coefficient were observed in all cases. Its average value for all the samples was approximately 0.9 , and there was no difference in individual research groups. The very low value of the ionic ratio of $\mathrm{K}:(\mathrm{Ca}+\mathrm{Mg})$ resulted from the low potassium content in the studied samples. Under conditions of managing the production of organic roughage, potassium deficiency can often take place, particularly after a longer use of such lands (Rérat et. al. 2009).

Table 2. Statistical parameters of the studied sward quality parameters

\begin{tabular}{|c|c|c|c|c|c|c|c|c|c|}
\hline \multirow[b]{2}{*}{ Parameters } & \multirow[b]{2}{*}{ unit } & \multicolumn{4}{|c|}{ without animal breeding } & \multicolumn{4}{|c|}{ farms with animal production } \\
\hline & & $\min$ & $\max$ & mean & median & $\min$ & $\max$ & mean & median \\
\hline $\mathrm{P}$ & \multirow{5}{*}{$\%$} & 0.071 & 0.215 & $0.123 \mathrm{a}$ & 0.123 & 0.113 & 0.252 & $0.167 b$ & 0.176 \\
\hline $\mathrm{K}$ & & 0.254 & 0.875 & $0.465 \mathrm{a}$ & 0.458 & 0.334 & 0.891 & $0.535 b$ & 0.526 \\
\hline $\mathrm{Ca}$ & & 0.139 & 0.356 & $0.266 \mathrm{a}$ & 0.294 & 0.190 & 0.501 & $0.325 b$ & 0.294 \\
\hline $\mathrm{Mg}$ & & 0.125 & 0.231 & $0.172 \mathrm{a}$ & 0.174 & 0.145 & 0.254 & $0.183 \mathrm{a}$ & 0.179 \\
\hline $\mathrm{Na}$ & & 0.007 & 0.056 & $0.022 \mathrm{a}$ & 0.023 & 0.008 & 0.100 & $0.029 \mathrm{a}$ & 0.023 \\
\hline $\mathrm{Ca}: \mathrm{P}$ & \multirow[t]{2}{*}{-} & 1.146 & 4.614 & 2.319 & 2.124 & 1.358 & 4.436 & 2.060 & 1.976 \\
\hline $\mathrm{K}:(\mathrm{Ca}+\mathrm{Mg})$ & & 0.402 & 1.525 & 0.882 & 0.827 & 0.469 & 1.306 & 0.882 & 0.771 \\
\hline
\end{tabular}


The results of the conducted research indicate that plants cultivated according to the principles of organic farming have a poor feed value. Low phosphorus, potassium and calcium content is the most determinant of poor feed quality. These elements are very important for animals, and their deficiency may result in health problems in bred animals. Feeding animals with feed only from the studied farms could lead to a reduction in their productivity and problems associated with managing their health. Chemical composition of the studied samples from farms with animal production is more beneficial than of those from farms without animal breeding. They are characterized by a higher content of almost all of the studied macroelements. None of the farms applies fertilization on certified lands, but in farms with animals grazing takes place periodically. Grazing animals are a source of readily available elements, which translates into botanical and chemical composition of sward (Assmann et al. 2014). The studied farms have organic plant production and parallel plant production in the traditional system. Such a strategy is connected with additional subsidies for organic production, which improves the condition of the entire farm (Wahlhütter et al. 2016). Feed produced on certified lands is intended for conventional animals which are additionally fed with traditional feeds (both roughages and concentrates). Moreover, most of the farms use mineral additives. Therefore, no health problems are observed. There are few organic farms with organic animal keeping in Poland (Cupiał et al. 2013). This is not beneficial from the point of view of the development of organic farming. However, under conditions of organic animal production, when feed is produced on farmers' own fields, the amount of available elements may decrease permanently. Permanent positive effect of organic agriculture, which lies at the basis of its ideological assumptions, would require implementing a rational fertilization policy.

The results of the conducted research indicate that biomass of plants from organic grass crops with small-seed legumes has improper chemical composition from the point of view of using it for feed purposes. Lack of mineral fertilization and a considerable reduction in the use of external means of production in organic farming generate a high risk of permanent negative balance of plant nutrients. This can lead to a disturbed homeostasis of agroecosystems and disturbed quantitative relations of elements in plant biomass (Nowak et al. 2015, Craheix et al. 2016).

\section{CONCLUSIONS}

1. The sward from grasses and small-seed legumes from the studied organic farms had too low content of macroelements and of most microelements.

\section{The studied feed had wrong mass ratio $\mathrm{Ca}: \mathrm{P}$ and ionic ratio $\mathrm{K}:(\mathrm{Ca}+\mathrm{Mg})$.}

3. The animal production farms were found to have a higher content of phosphorus, calcium and potassium in sward as compared to farms without animals.

4. Feeding cattle only with roughage obtained from the studied lands could pose a risk to the health of the animals and their productive abilities owing to the unfavorable chemical composition.

\section{REFERENCES}

Alvarez-Fuentes G. Appuhamy J.A.D.R.N. Kebreab E. (2016). Prediction of phosphorus output in manure and milk by lactating dairy cows. Journal of Dairy Science, 99, 1, 771-782.

Anglade J., Billen G., Garnier J., Makridis T., Puech T., Tittel C. (2015). Nitrogen soil surface balance of organic vs conventional cash crop farming in the Seine watershed. Agricultural Systems, 139, 82-92. 
Assmann J.M., Anghinoni I., Posselt Martins A., Valao S.E., de Andrade Costa G., Cecagno D., Selau Barszczewski J., Jankowska-Huflejt H., Wolicka M. (2007). Bilans azotu, fosforu i potasu w zróżnicowanych obszarowo gospodarstwach ekologicznych. Journal of Research and Applications in Agricultural Engineering, 52, 3, 5-9.

Carlos F., Cesar P., de Faccio Carvalho P.C. (2014). Soil carbon and nitrogen stocks and fractions in along-termintegrated crop-livestock system under no-tillage in southern Brazil. Agriculture, Ecosystems and Environment, 190, 52-59.

Carlsson, F., Khanh Nam, P., Linde-Rahr, M., Martinsson, P. (2007). Are Vietnamese farmers concerned with their relative position in society? The Journal of Development Studies 43, 7 1177-1188.

Craheix D., Angevin F., Doré T., de Tourdonnet S. (2016). Using a multicriteria assessment model to evaluate the sustainability of conservation agriculture at the cropping system level in France. European Journal of Agronomy. 76, 75-86.

Cupiał M., Klimas A., Szeląg-Sikora A., Niemiec, M., Sikora J. (2013). Problem gospodarowania składnikami pokarmowymi roślin w gospodarstwach ekologicznych. Proceedings of ECOpole, 7(2), 553559.

Eisenberg S.W.F., Ravesloot L., Koets A.P. and Grünberg W. (2014). Influence of feeding a low phosphorus diet on leucocyte function in dairy cows. Journal Dairy Science, 97, 5176-5184.

Falkowski M., Kukułka I., Kozłowski S. (2000). Właściwości chemiczne roślin łąkowych. Wyd. AR Poznań, 132.

Granzin B., Gaughan J.B. (2002). The effect of sodium chloride supplementation on the milk production of grazing Holstein Friesian cows during summer and autumn in a humid sub-tropical environment. Animal Feed Science and Technology, 96, 3-4, 147-160.

Higgins V., Dibden J., Cocklin C. (2008). Neoliberalism and natural resource management: Agrienvironmental standards and the governing of farming practices. Geoforum, 39, 5, 1776-1785. Kuboń M. Krasnodębski A. (2010). Logistic cost in competitive strategies of enterprises. Agricultural Economics, 56, 397-402.

Kulik M. (2009). Effect of different factors on chemical composition of Gras- legumes sward. Journal of. Elementology. 14, 1, 91-100.

Lorenz K., Lal R. (2016). Chapter Three - Environmental Impact of Organic Agriculture. Advances in Agronomy, 139, 99-152.

McDowell, L.R. (1996). Feeding minerals to cattle on pasture. Animal Feed Science and Technology, 60, 247- 271.

McNamara JP, Auldist MJ, Marett LC, Moate PJ, Wales WJ. (2017). Analysis of pasture supplementation strategies by means of a mechanistic model of ruminal digestion and metabolism in the dairy cow.

Journal of Dairy Science, 100, 2, 1095-1106.

Niemiec M., Sikora J., Szeląg-Sikora A. (2016). Evaluation of metfod production in terms of implementation of organic farming in Poland. Journal of Research and Applications in Agricultural Engineering, 61(4) 72-76.

Niemiec M., Sikora J., Szelag-Sikora A., Kubon M., Olech E., \& Marczuk, A. (2017). Applicability of food industry organic waste for methane fermentation. Przemyst Chemiczny, 96, 3, 685-688.

Niemiec M., Szeląg-Sikora A., Cupiał M. (2015). Evaluation of the Efficiency of Celeriac Fertilization with the Use of Slow-acting Fertilizers. Agriculture and Agricultural Science Procedia, 7, 177-183.

Nowak B., Nesme T, David C., Pellerin S. (2015). Nutrient recycling in organic farming is related to diversity in farm types at the local level. Agriculture, Ecosystems \& Environment, 204, 1,17-26, doi.org/10.1016/j.agee.2015.02.010.

Rérat M., Philipp A., Hess H.D. Liesegang A. Effect of different potassium levels in hay on acid-base status and mineral balance in periparturient dairy cows. Journal of Dairy Science, 92, 12, 6123-6133. Tabor. S. Cupiał M. (2001). Energy and labour consumption of agricultural production. Farm work science facing the challenges of the XXI century. Proceedings XXIX CIOSTA GIGR V Congress, 154157.

Wahlhütter S., Vogl C.R., Eberhart H. (2016). Soil as a key criteria in the construction of farmers' identities: The example of farming in the Austrian province of Burgenland. Geoderma 269, 39-53. Zielińska K.J., Fabiaszewska A.U., Wróbel B. (2014). Assessment of the quality of sward from the grasslands of selected organic farms. Journal of Research and Applications in Agricultural Engineering, $59,4,131-136$ 